\title{
Introduction
}

\section{Scott Shane}

\section{THE PURPOSE}

Entrepreneurship is often seen by policy makers as a key mechanism for enhancing economic development, particularly in regions where entrepreneurial activity was once vibrant and is now lagging. To policy makers, entrepreneurship is a good solution because it provides a relatively noncontroversial way to increase the proverbial pie, creating jobs and enhancing per capita income growth. Therefore government officials frequently search for mechanisms to enhance entrepreneurial activity in their regions, whether those mechanisms are tax policies, financing subsidies or other tools.

Universities are also seen as valuable institutions for economic development. Perhaps because the primary mission of universities is education, and education is viewed by virtually everyone as good, and perhaps because universities are among the most geographically stable entities in existence, rarely relocating to other locales, policy makers often look to ways to turn universities in their regions into engines of economic development. Mechanisms to enhance technology transfer from universities, to reduce brain drain out of a region, and policies to create linkages between universities and industry are among the many efforts chosen by policy makers to use universities to enhance regional economic development.

Recently anecdotal evidence has begun to emerge to suggest that these two economic development efforts are not independent. Policy makers are beginning to examine the role of universities as entities to enhance economic development in regions through their effect on entrepreneurial activity. Whether the anecdotes focus on the creation of university spin-off companies to exploit intellectual property created at universities to create jobs and enhance productivity in a region, or they focus on ways to use universities to attract and train women and minority entrepreneurs who otherwise would not settle in a region, the message is clear. Policy makers are beginning to think about universities as facilitating economic development through entrepreneurship, and are searching for policy levers to enhance

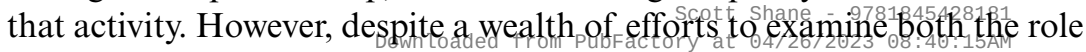


of entrepreneurs in economic development and the role of universities in economic development, no systematic effort has been made to examine the intersection of these two sets: the role of universities to enhance economic development through entrepreneurship.

This book seeks to fill this gap. The result of a workshop at Case Western Reserve University in which scholars were invited to present their views on the linkages between government, university and business efforts to promote economic development through entrepreneurship, the book aims to provide a systematic review of what we know about effective policies in this area. Each chapter focuses on a linkage in a different domain, such as technology transfer, education and so on. The authors present both best practices and problematic strategies for joint efforts by governments, industries and universities to promote economic development through entrepreneurship.

Many chapters are followed by commentary presented by a 'thoughtful practitioner'. The idea behind the commentaries is to present an evaluation of the academic's arguments from the perspective of someone directly involved in government-university-industry partnerships.

The chapters are non-technical and summarize existing knowledge and research on the topic rather than produce new primary research. The goal of the book is to help government policy makers, foundations, university officials, business leaders and other stakeholders interested in figuring out how to create partnerships between universities and governments to encourage economic development through entrepreneurship.

\section{THE CHAPTERS}

The first chapter, 'An historical perspective on government-university partnerships to enhance entrepreneurship and economic development', by Irwin Feller, traces the history of two important efforts by American universities to enhance economic growth: university-government-industry programs in research and development, and academic programs to foster entrepreneurship. The chapter traces the history of government-university-industry partnerships to promote economic development from the colonial period to the present, focusing on the major shifts in those efforts, including the creation of the land grant system, the role of universities to the war effort in World War II, and the Bayh-Dole Act. The main conclusions of Feller's historical review are that government-industry-university research and development partnerships appear to be working effectively, but could face challenges from federal budget deficits and state boom and bust policy shifts. These programs also remain a relatively small part of research and

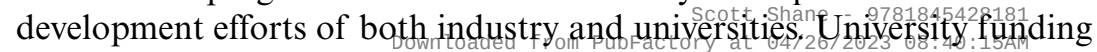


of research and development at American universities may even decline further as conflict emerges over ownership of intellectual property.

The second chapter, 'Government policies to encourage economic development through entrepreneurship: the case of technology transfer', by Scott Shane, reviews the effects that university spin-offs have on economic development, as well as policies that federal and state governments have employed successfully to enhance the development of these companies. The chapter explains that many important high-technology companies were spin-offs from universities, that spin-offs commercialize many technologies that otherwise would go uncommercialized, induce greater amounts of investment than other licensees, and tend to locate close to the universities that spawn them. The chapter points to six policies that enhance spinoff company creation: (1) intense federal funding of academic research, (2) awarding of property rights to universities rather than inventors, (3) awarding the ownership of federally funded inventions to universities, (4) subsidizing new technology creation through incubators or other institutional mechanisms, (5) financing pre-market stage investment in technology development by new companies, and (6) creating policies, such as those that support leave of absence from academic positions, and ownership of equity in spin-off companies, to encourage academic participation in spin-off company creation.

The third chapter, 'Creating innovation networks among manufacturing firms: how effective extension programs work', by Susan Helper and Marcus Stanley, examines component manufacturing firms of fewer than 500 employees to determine the sources of their productivity and policies that help them enhance that productivity. The authors find that firms in urban areas are more productive, but that productivity benefits accrue to workers, not firms. Social networks increase the productivity of firms, and firms that do more engineering gain more from being in urban locations. Moreover urban location appears to help high wage-high skill manufacturing firms weather adverse trends. The authors recommend three categories of policies to help enhance the productivity of these small manufacturing firms: tax reduction, subsidies for training or research and development, and changing the way firms produce goods. The authors are largely agnostic on whether government programs should focus more on helping small firms than large firms, but offer several reasons why a focus on small firms might be beneficial. External ideas have greater effects on small firm productivity than on large firm productivity and small firms are more likely than large firms to stay in the region. However small firms may not benefit the most from government programs because of their lower wages and relative lack of technical skills. 
The fourth chapter, 'Investing in the MEMS regional innovation networks and the commercialization infrastructure of older industrial states', by Michael Fogarty, examines the case of microelectrical mechanical systems as a case study of value to a locality in developing a systems approach to economic development, combining public and private sector innovation to enhance economic development. The chapter asks how localities with a disadvantaged technological position can improve that position. It answers that the locality must analyze the situation using a systems approach and then use the analysis to focus investment in key areas.

The fifth chapter, 'Buying Ohioans loyalty? How state financial aid affects brain drain', by Eric Bettinger and Erin Riley, addresses the issue of brain drain. It identifies the mechanisms through which college financial aid increases the probability that students will stay in a state. The chapter shows that the main mechanism is keeping students in the state longer so that life events, which reduce the probability of departure, occur in the state.

The sixth chapter, 'On SBA-guaranteed lending and economic growth', by Ben Craig, William Jackson and James Thomson, examines whether SBA-guaranteed loans to small business enhances local economic growth. Arguing that SBA guarantees might reduce information problems in small business finance, thereby reducing credit rationing, the authors find that the level of SBA loan guarantees across counties is positively related to growth in personal income in those counties.

The seventh chapter, 'Smart places for smart people: cluster-based planning in the 21 st-century knowledge economy', by Michael Luger, describes the effort by the state of North Carolina to use an industry clustering process to identify industries for policy makers to focus their attention upon, not just on the basis of industry codes, but also on the basis of occupations and technologies. The chapter shows how industries can expand on more traditional methods of industry clustering to identify where to invest for new, knowledge-based, industries.

The eighth chapter, 'Regional wealth creation and the 21 st century: women and "minorities" in the tradition of economic strangers', by John Butler, reviews the literature on the contribution of women and minority entrepreneurs to economic development. Drawing on the theoretical lens of in-group and out-group membership, Butler explains that women and minority entrepreneurs enhance economic development because they are often strangers to the existing social and economic system in a region. By bringing in new skills and knowledge, these groups enhance economic development within the region.

The final chapter, 'Universities, entrepreneurship and public policy: lessons from abroad', by Bo Carlsson, compares entrepreneurial activities

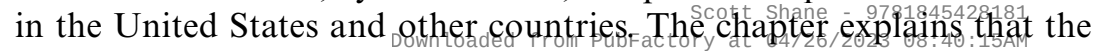


legal and economic environment for such activity differs between the USA and elsewhere. As a result, the focus of this activity in the USA is on technology transfer, whereas elsewhere it is on regional innovation systems and spillover mechanisms. The main policy implications of the chapter are that institutional arrangements matter a great deal, in particular the ownership of intellectual property by universities in the USA. The other major policy implication is that one needs a systems approach incorporating both supply and demand, to understand the phenomenon, with the USA providing the major lessons on the supply side, and Europe the major lessons on the demand side. 